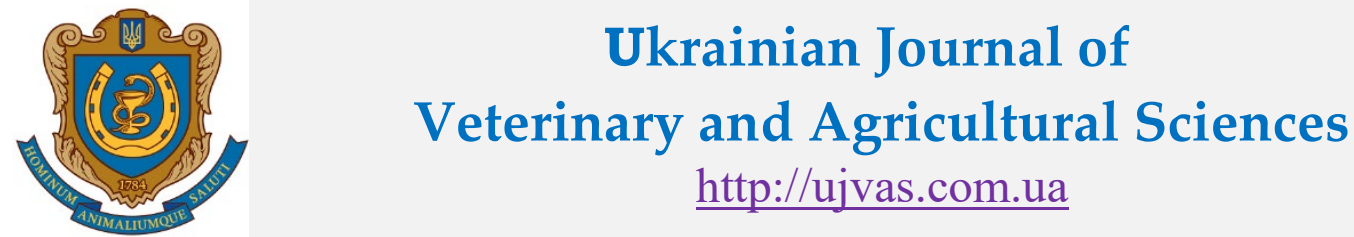

Stepan Gzhytskyi National University of Veterinary Medicine and Biotechnologies Lviv

\begin{tabular}{l|l|l} 
original article & UDC 606:637.3:637.055 & doi: 10.32718/ujvas3-3.03
\end{tabular}

Volume 3

Number 3

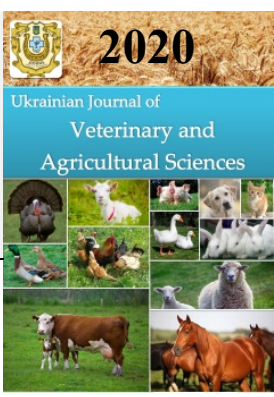

\title{
The ability of enterococci extracted from traditional Carpathian cheese bryndza to produce biologically active substances
}

\author{
I. I. Kushnir ${ }^{1}$, O. Y. Tsisaryk ${ }^{1}$, S. H. Shalovylo ${ }^{1}$, B. V. Gutyj ${ }^{1}$, G. V. Kushnir ${ }^{2}$, I. M. Slyvka ${ }^{1}$, L. Y. Musiy ${ }^{1}$

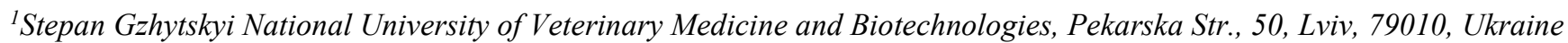 \\ ${ }^{2}$ State Scientific-Research Control Institute of Veterinary Medicinal Products and Feed Additives, Donetska Str., 11, Lviv, \\ 79019, Ukraine
}

\begin{tabular}{|c|}
\hline $\begin{array}{l}\text { Article info } \\
\text { Received 06.07.2020 } \\
\text { Received in revised form } \\
\quad 05.08 .2020 \\
\text { Accepted } 06.08 .2020\end{array}$ \\
\hline $\begin{array}{l}\text { Correspondence author } \\
\text { Iryna Kushnir } \\
\text { Tel.: +38-098-290-16-94 } \\
\text { E-mail: irynakushn@gmail.com }\end{array}$ \\
\hline $\begin{array}{l}2020 \text { Kushnir I. et al. This is an } \\
\text { open-access article distributed } \\
\text { under the terms of the Creative } \\
\text { Commons Attribution License, } \\
\text { which permits unrestricted use, } \\
\text { distribution, and reproduction in } \\
\text { any medium, provided the } \\
\text { original author and source are } \\
\text { credited. } \\
\begin{array}{l}\text { (cc) Br } \\
\text { Br }\end{array}\end{array}$ \\
\hline
\end{tabular}

Contents

1. Introduction

2. Materials and methods ......... 15

3. Results and discussion

4. Conclusions ................. 18

References .................... 18

\begin{abstract}
The article presents the results of determining the ability of enterococci extracted from traditional Carpathian cheese bryndza to produce biologically active substances, in particular, amino acids, B vitamins and cations (ammonium, potassium, sodium, magnesium, calcium). It was found that the studied strains of enterococci in different quantities synthesized both essential and essential amino acids. Thus, the essential amino acid lysine was found in the cultivation of strains of E. durans SB18, E. durans SB20, in particular, its concentration was significantly increased by 15.6 and $10.4 \%$, respectively $(\mathrm{P}<0.05)$ compared to the control. A probable increase in the essential amino acid histidine by 20 and $53.3 \%(\mathrm{P}<0.05)$ was detected in the cultivation of only E. faecium SB12 and E. durans SB18. In addition, it was found a probable increase in threonine synthesis by enterococci $E$. durans SB6 and $E$. durans SB18, respectively -33.3 and $39.6 \%(\mathrm{P}<0.05)$. The replacement amino acid serine was able to synthesize strains of E. faecium SB12, E. durans SB18 and E. durans SB20, while its concentration increased by $40.0(\mathrm{P}<0.001), 30.0$ and $35.0 \%$, respectively $<0.01)$, and strains of $E$. durans, SB6, and E. durans SB18 synthesized glycine, the concentration of which increased by -10.2 and $16.2 \%$, respectively $(\mathrm{P}<0.01)$. In addition, it was found that the studied strains in small quantities synthesized B vitamins, or not synthesized at all. In all experimental samples the most vitamin B1 was detected, its concentration increased from 8.5 to 10.0 times $(\mathrm{P}<0.001)$. Riboflavin was synthesized by three strains of enterococci - E. durans SB6, E. durans SB18, E. durans SB20, so the concentration of vitamin B2 probably increased, respectively, 4.1, 2.0 and 2.0 times $(\mathrm{P}<0.05)$. Enterococci E. durans SB6, E. faecium SB12, E. durans SB18 and E. durans SB20 synthesized in significant quantities only vitamin $\mathrm{B} 3$, in particular, its concentration probably increased by $1.5,1.5(\mathrm{P}<0.05)$, respectively, $1.5(\mathrm{P}<0.01)$ and $1.6(\mathrm{P}<0.001)$ times, and vitamin $\mathrm{B} 5$ was produced by E. faecium SB12, E. durans SB18 and E. durans SB20, the concentration of nicotinic acid increased, respectively, $2.9(\mathrm{P}<0.05), 8.4$ and $9.5(\mathrm{P}<0.001)$ times. Analysis of the macroelement composition of the supernatant of enterococci showed that strains of $E$. durans, SB6, E. faecium SB12, E. durans SB18 and E. durans SB20 are able to produce only Calcium, in particular, found a probable increase, respectively, in $1.8,2.4,1.6$ and 1.4 times $(\mathrm{P}<0.05)$.
\end{abstract}

Key words: Enterococcus durans, E. faecium, vitamins, amino acids, macronutrients.

\section{Citation:}

Kushnir, I. I., Tsisaryk, O. Y., Shalovylo, S. H., Gutyj, B. V., Kushnir, G. V., Slyvka, I. M., \& Musiy L. Y. (2020). The ability of enterococci extracted from traditional Carpathian cheese bryndza to produce biologically active substances. Ukrainian Journal of Veterinary and Agricultural Sciences, 3(3), 15-19.

\section{Introduction}

Human health largely depends on nutrition, as a lack or deficiency of nutrients causes a violation of the general condition and a decrease in the body's immune system (Omelchuk et al., 2010; Musiy et al., 2017; Tsisaryk et al., 2018; Gachak et al., 2019). When developing innovative and improving existing technologies for the production of dairy products, it is important to introduce functional products into human nutrition in order to prevent disease and premature aging (Didukh, 2008). Functional products derived from natural ingredients contain a large number of biologically active substances that can stimulate immune responses in the body and prevent disease (Richardson, 2002; Kapreliants \& Iorhachova, 2003; Hachak et al., 2018).
Taking into account abovementioned, an important task of food biotechnology is to obtain functional products that contain and promote the development of beneficial bacteria. The normal intestinal microflora of the macroorganism plays an extremely important role in the prevention of beriberi and enzymatic disorders. In addition, the normoflora promotes endogenous synthesis of nucleotides, essential amino acids and peptides, regulates adaptation processes and the formation of a protective barrier of the intestinal mucosa (Heyman et al., 2005). However, under adverse conditions, there are changes in the ratio of normal microflora of the digestive tract, which leads to dysbacteriosis (Tkach et al., 2014). In such cases, it is advisable to use probiotics, and the strains of bacteria that are part of them, are selected according to the ability to produce various bio- 
logically active substances and they must show synergism (Tarasenko \& Filippova, 2014). The advantages of probiotics are the prevention of infectious diseases and food allergies, lowering serum cholesterol, anticancer activity, immunoadjuvant properties and improving the absorption of lactose (Soccol et al., 2010). That is why the processes of microbial fermentation in the large intestine affect not only the normal functioning of the digestive system, but also the state of the body as a whole (Lahtin et al., 2008). Normal microflora, due to fermentation activity, is able to synthesize biologically active substances, in particular, organic acids, alcohols, lipids, B vitamins, etc (Gottshalk, 1982).

Vitamins are precursors of intracellular coenzymes needed to regulate biochemical reactions in the cell. Humans and animals are not able to synthesize most vitamins, so they must come with food. Although most vitamins are part of a variety of foods, however, vitamin deficiencies still exist. For this reason, many countries have adopted laws on the forced fortification of certain products with appropriate vitamins and minerals, however, some countries have not adopted this program due to possible side effects (Asrar \& O'Connor, 2005; Blencowe et al., 2010).

That is why the alternative to chemically synthesized products are vitamins synthesized by microorganisms, because they do not cause side effects. Along with the positive effect of vitamins on the body of humans and animals, an important role is played by macro- and microelements, so of the 118 known chemical elements, 81 were found in the human body (Levitin et al., 2017). Among them are indispensable (calcium, potassium, sodium, manganese, magnesium, sulfur, iron) imbalance which causes clinical symptoms. Trace elements in the body act as cofactors of enzymes $(\mathrm{Zn}, \mathrm{Mg}, \mathrm{Mn}, \mathrm{Mo}, \mathrm{Cu}, \mathrm{Fe})$ and can be structural components of molecules $(\mathrm{Ca}, \mathrm{J}, \mathrm{Cr}, \mathrm{Co}$, etc.). Aging, various diseases, intense physical activity and bad habits cause a decrease in the content of macro- and microelements in the human body, in particular, deficiency of J, Fe, Ca, F and Se is found in $90 \%$ of the population of Ukraine (Korzun et al., 2007). Macro- and microelements in the human body are not synthesized, and their balance is maintained by the receipt of food (Orlov, 1998).

Taking into account abovementioned, while the creation of new bacterial fermenting drugs an important ability of probiotic microorganisms is the production of biologically active substances (Tarasenko \& Filippova, 2014).

Therefore, the aim of the research was to establish the ability of enterococci E. durans SB6, E. faecium SB12, E. durans SB18, E. durans SB20, isolated from traditional Carpathian cheese bryndza (Slyvka et al., 2018), to produce biologically active substances and some macronutrients.

\section{Materials and methods}

Determination of qualitative and quantitative content of biologically active substances and some macronutrients in the experimental samples was performed by capillary electrophoresis using the device "Kapel-105/105M", which is equipped with special software. The method is based on electrokinetic phenomena, electromigration of ions and other charged particles and electroosmosis, which occur in solutions when they are placed in an electric field, mainly high voltage. When the solution is in a thin capillary, the electric field along the capillary causes it to move charged particles and passive fluid flow, causing the sample to split into individual components, as the electromigration parameters are specific to each type of charged particle.

When determining the qualitative and quantitative composition of amino acids and cations (ammonium, potassium, sodium, magnesium, calcium), $1 \mathrm{~cm}^{3}$ of supernatant of the corresponding enterococci grown on liquid MPC medium for $48 \mathrm{~h}$ at a temperature of $37^{\circ} \mathrm{C}$ was added to the hydrolysis vials and $9 \mathrm{~cm}^{3}$ were added. hydrochloric acid. They were sealed, stirred and hydrolyzed at $110{ }^{\circ} \mathrm{C}$ for 14 16 hours. After hydrolysis, the contents of the vial were cooled to room temperature and filtered through a blue tape filter, discarding the first portions. To determine amino acids in glass vials were taken $0.05 \mathrm{~cm}^{3}$ of hydrolyzate and evaporated in a stream of warm air. $0.15 \mathrm{~cm}^{3}$ of sodium carbonate solution and $0.3 \mathrm{~cm}^{3}$ of FITC solution were added to each dry residue vial, mixed thoroughly to dissolve the precipitate and left for 35 minutes at room temperature. Then the solutions were dried dry in a stream of warm air. The dry residue was dissolved in $0.5 \mathrm{~cm}^{3}$ of double-distilled water and used for the study. Detection of amino acids was performed at a wavelength of $254 \mathrm{~nm}$.

To determine the mass fraction of cations in glass boxes, $0.50 \mathrm{~cm}^{3}$ of hydrolyzate was taken and evaporated in a stream of warm air. The dry residue was dissolved in $0.50 \mathrm{~cm}^{3}$ of distilled water and cations were determined in the test samples. Detection was performed at a wavelength of $267 \mathrm{~nm}$.

To determine the qualitative and quantitative composition of $\mathrm{B}$ vitamins, $1 \mathrm{~cm}^{3}$ of the supernatant of the corresponding enterococci grown on liquid MPC medium for $48 \mathrm{~h}$ was added to the dark glass vials and $4 \mathrm{~cm}^{3}$ of working solution for vitamin extraction was added. The test vials were placed on a boiling water bath for 5 minutes, then cooled, centrifuged in Eppendorf tubes, and vitamins detected at 200 and $267 \mathrm{~nm}$ wavelengths.

When determining the amino acid composition, the content of $\mathrm{B}$ vitamins and the content of cations (ammonium, potassium, sodium, magnesium, calcium) in the studied samples at the initial stage of work, calibration graphs were constructed and the stability of control solutions was checked. In addition, the width of the identification window was set and the automatic identification of the studied indicators was checked on the received electrophoregrams.

The obtained values were satisfactory, because according to the certified research methodology, the deviation at each point of the graduated characteristic did not exceed 5-8\%, which further allowed to carry out the planned research.

\section{Results and discussion}

The obtained data on the determination of amino acids in the experimental samples (Table 1) indicate that the studied strains of enterococci in different quantities synthesized both essential and non-essential amino acids. It was found that all four strains of enterococci used for their diet such essential amino acids as tyrosine and proline, as well as essential methionine. The essential amino acid lysine was synthesized in various amounts by all strains of enterococci. However, a probable increase in the level of this amino acid was observed in the cultivation of strains of E. durans SB18, E. durans SB20, in particular, its concentration was significantly increased by 15.6 and $10.4 \%(\mathrm{P}<0.05)$, respectively, compared to the control. Phenylalanine and alanine were not 
synthesized by all studied strains of enterococci, but were not used in the diet. A probable increase in the essential amino acid histidine by 20 and $53.3 \%(\mathrm{P}<0.05)$ was detected in the cultivation of strains of E. faecium SB12 and E. durans SB18.

A slight increase in the essential amino acids leucine + isoleucine occurred in the cultivation of E. durans SB6 and E. faecium SB12 and E. durans SB18. There was also a probable increase in trethionine synthesis by enterococci
E. durans SB6 and E. durans SB18, respectively, by 33.3 and $39.6 \%(\mathrm{P}<0.05)$. The replacement amino acid serine was able to be synthesized by strains of E. faecium SB12, E. durans SB18 and E. durans SB20, and its concentration increased by 40.0 ( $\mathrm{P}<0.001), 30.0$ and $35.0 \%$, respectively $(\mathrm{P}<0.01)$, and strains of $E$. durans $\mathrm{SB} 6$ and $E$. durans SB18 synthesized glycine, the concentration of which increased by 10.2 and $16.2 \%$, respectively $(\mathrm{P}<0.01)$.

Table 1

Amino acid composition of test samples $(M \pm m, n=3)$

\begin{tabular}{|c|c|c|c|c|c|}
\hline \multirow{2}{*}{ Amino acids } & \multirow{2}{*}{ Control } & \multicolumn{4}{|c|}{ Strains of enterococci } \\
\hline & & $S B 6$ & $S B 12$ & $S B 18$ & $S B 20$ \\
\hline Arginine, $\%$ & $0.051 \pm 0.002$ & $0.032 \pm 0.001$ & $0.055 \pm 0.002$ & $0.029 \pm 0.001$ & $0.029 \pm 0.003$ \\
\hline Lysine, \% & $0.077 \pm 0.003$ & $0.081 \pm 0.001$ & $0.079 \pm 0.004$ & $0.089 \pm 0.003 *$ & $0.085 \pm 0.001 *$ \\
\hline Tyrosine, $\%$ & $0.030 \pm 0.012$ & $0.019 \pm 0.002 * *$ & $0.019 \pm 0.001 * *$ & $0.016 \pm 0.001 * *$ & $0.016 \pm 0.001 * *$ \\
\hline Phenylalanine, \% & $0.048 \pm 0.001$ & $0.049 \pm 0.002$ & $0.050 \pm 0.004$ & $0.049 \pm 0.004$ & $0.050 \pm 0.002$ \\
\hline Histidine, $\%$ & $0.015 \pm 0.001$ & $0.014 \pm 0.002$ & $0.018 \pm 0.001 *$ & $0.023 \pm 0.004 *$ & $0.016 \pm 0.001$ \\
\hline Leucine + isoleucine, $\%$ & $0.120 \pm 0.001$ & $0.123 \pm 0.001$ & $0.112 \pm 0.001$ & $0.127 \pm 0.002 *$ & $0.103 \pm 0.004 *$ \\
\hline Methionine, $\%$ & $0.033 \pm 0.008$ & $0.019 \pm 0.002$ & $0.016 \pm 0.003$ & $0.028 \pm 0.004$ & $0.016 \pm 0.002$ \\
\hline Valine, $\%$ & $0.049 \pm 0.002$ & $0.043 \pm 0.002$ & $0.031 \pm 0.002 * *$ & $0.056 \pm 0.006$ & $0.025 \pm 0.001 * * *$ \\
\hline Proline, \% & $0.103 \pm 0.002$ & $0.101 \pm 0.002$ & $0.092 \pm 0.004$ & $0.095 \pm 0.0024$ & $0.080 \pm 0.003 * *$ \\
\hline Threonine, $\%$ & $0.048 \pm 0.002$ & $0.064 \pm 0.005^{*}$ & $0.047 \pm 0.005$ & $0.067 \pm 0.004 *$ & $0.053 \pm 0.006$ \\
\hline Serine, $\%$ & $0.040 \pm 0.0007$ & $0.039 \pm 0.002$ & $0.056 \pm 0.001 * * *$ & $0.052 \pm 0.001 * *$ & $0.054 \pm 0.001 * *$ \\
\hline Alanine, $\%$ & $0.095 \pm 0.001$ & $0.094 \pm 0.001$ & $0.0899 \pm 0.001 *$ & $0.113 \pm 0.006$ & $0.099 \pm 0.003$ \\
\hline Glycine, \% & $0.167 \pm 0.002$ & $0.184 \pm 0.002 * *$ & $0.167 \pm 0.007$ & $0.194 \pm 0.011^{* *}$ & $0.171 \pm 0.004$ \\
\hline
\end{tabular}

Note: ${ }^{*}-\mathrm{P}<0.05 ; * *-\mathrm{P}<0.01 * * * ;-\mathrm{P}<0.001$

As can be seen from the results of studies of B vitamins (Table 2), the studied strains synthesized vitamins in small quantities, or not synthesized at all, in particular, this applies to vitamin $\mathrm{B}_{6}$ and Sun. Vitamin $\mathrm{B}_{6}$ in small quantities was synthesized only by the strain E. durans SB6, and folic acid - E. durans SB18, and all other strains, apparently, used them for their nutrition. In all experimental samples the most vitamin $\mathrm{B}_{1}$ was detected, its concentration increased from 8.5 to 10.0 times $(\mathrm{P}<0.001)$. Riboflavin was synthesized by three strains of enterococci $-E$. durans SB6, E. durans SB18, E. durans SB20, so the concentration of vitamin $\mathrm{B}_{2}$ probably increased, respectively, 4.1, 2.0 and 2.0 times $(\mathrm{P}<0.05)$, and the E. faecium SB12 strain apparently used this vitamin, so it was not detected. It should be noted that all four strains of enterococci E. durans, SB6, E. faecium SB12, E. durans SB18 and E. durans SB20 synthesized a significant amount of vitamin $\mathrm{B}_{3}$, in particular, its concentration probably increased by $1.5,1.5$, respectively $(\mathrm{P}<0.05), 1.5(\mathrm{P}<0.01)$ and $1.6(\mathrm{P}<0.001)$ times. The three strains of enterococci E. faecium SB12, E. durans SB18 and E. durans SB20 were able to synthesize large amounts of vitamin $\mathrm{B}_{5}$, so the concentration of nicotinic acid increased, respectively, in $2.9(\mathrm{P}<0.05), 8.4$ and 9.5 $(\mathrm{P}<0.001)$ times.

Table 2

Vitamin composition of experimental samples, $(\mathrm{M} \pm \mathrm{m}, \mathrm{n}=3)$

\begin{tabular}{cccccc}
\hline \multirow{2}{*}{ Vitamin } & \multirow{2}{*}{ Control } & \multicolumn{4}{c}{ Strains of enterococci } \\
\cline { 3 - 6 } & & $S B 6$ & $S B 12$ & $S B 18$ & $S B 20$ \\
\hline Vitamin $\mathrm{B}_{1}, \%$ & $0.066 \pm 0.003$ & $0.633 \pm 0.032^{* * *}$ & $0.566 \pm 0.027^{* * *}$ & $0.586 \pm 0.042^{* * *}$ & $0.586 \pm 0.023^{* * *}$ \\
Vitamin $\mathrm{B}_{2}, \%$ & $0.013 \pm 0.003$ & $0.053 \pm 0.009^{*}$ & nd & $0.026 \pm 0.001^{*}$ & $0.026 \pm 0.003^{*}$ \\
Vitamin $\mathrm{B}_{3}, \%$ & $0.443 \pm 0.023$ & $0.643 \pm 0.055^{*}$ & $0.643 \pm 0.027^{* *}$ & $0.663 \pm 0.041^{* *}$ & $0.710 \pm 0.01 * * *$ \\
Vitamin $\mathrm{B}_{5}, \%$ & $0.046 \pm 0.003$ & nd & $0.133 \pm 0.018^{*}$ & $0.386 \pm 0.031^{* * *}$ & $0.436 \pm 0.042^{* *}$ \\
Vitamin $\mathrm{B}_{6}, \%$ & $0.036 \pm 0.003$ & $0.023 \pm 0.0088$ & nd & nd & nd \\
Vitamin $\mathrm{Bc}, \%$ & $0.27 \pm 0.007$ & nd & nd & $0.31 \pm 0.020$ & nd \\
\hline
\end{tabular}

Note: * $-\mathrm{P}<0.05 ; * *-\mathrm{P}<0.01 * * * ;-\mathrm{P}<0.001$ nd - not detected 
Table 3

Macronutrients of experimental samples $(M \pm m, n=3)$

\begin{tabular}{clllll}
\hline \multirow{2}{*}{ Macroelements } & \multirow{2}{*}{ Control } & \multicolumn{4}{c}{ Strains of enterococci } \\
\cline { 3 - 6 } & & \multicolumn{1}{c}{$S B$ SB 12 } & \multicolumn{1}{c}{$S B$ 18 } & \multicolumn{1}{c}{$S B$ 20 } \\
\hline $\mathrm{Am}, \%$ & $0.226 \pm 0.002$ & $0.032 \pm 0.001$ & $0.032 \pm 0.002$ & $0.031 \pm 0.0006$ & $0.030 \pm 0.0003$ \\
$\mathrm{~K}, \%$ & $0.112 \pm 0.005$ & $0.108 \pm 0.004$ & $0.115 \pm 0.003$ & $0.112 \pm 0.003$ & $0.111 \pm 0.004$ \\
$\mathrm{Na}, \%$ & $0.249 \pm 0.004$ & $0.243 \pm 0.009$ & $0.247 \pm 0.008$ & $0.259 \pm 0.007$ & $0.248 \pm 0.009$ \\
$\mathrm{Mg}, \%$ & $0.005 \pm 0.0003$ & $0.005 \pm 0.0003$ & $0.005 \pm 0.0003$ & $0.005 \pm 0.0003$ & $0.004 \pm 0.0003$ \\
$\mathrm{Ca}, \%$ & $0.005 \pm 0.0003$ & $0.009 \pm 0.002^{*}$ & $0.012 \pm 0.004^{*}$ & $0.008 \pm 0.002^{*}$ & $0.007 \pm 0.001^{*}$ \\
\hline Note $*-\mathrm{P}<0.05$ & & & & &
\end{tabular}

Analysis of the results of studies to determine the content of cations (ammonium, potassium, sodium, magnesium, calcium) in the supernatant of enterococci, which are shown in table 3 , showed that only calcium was present in significant quantities. In particular, a probable increase of 1.8, 2.4, 1.6 and 1.4 times $(\mathrm{P}<0.05)$ in the content of Calcium in the supernatant, where cultured, respectively, strains of $E$. $d u$ rans SB6, E. faecium SB12, E durans SB18 and E. durans $\mathrm{SB} 20$. For other macronutrients, no significant differences compared to the control were found.

\section{Conclusions}

1. The strains of enterococci E. durans, SB6, E. faecium $\mathrm{SB} 12$, E. durans $\mathrm{SB} 18$ and E. durans SB20 extracted from traditional Carpathian cheese bryndza are capable of synthesis of biologically active substances. The studied strains in different quantities synthesize both essential and essential amino acids. It was found that the strain E. durans SB18, synthesizes the largest number of amino acids, in particular essential amino acids - lysine, trethionine and leucine + isoleucine, the concentration of which was higher, respectively, by $10.3,39.5(\mathrm{P}<0.05)$ and $5.8 \%$ than in the control, as well as the amino acids serine and glycine, the concentration of which was, respectively, 30.0 and $16.2 \%$ $(\mathrm{P}<0.01)$ higher compared to the control.

2. In all experimental samples the most vitamin $B_{1}$ was detected, its concentration increased from 8.5 to 10.0 times $(\mathrm{P}<0.001)$. Enterococci E. durans, SB6, E. faecium SB12, E. durans $\mathrm{SB} 18$ and E. durans $\mathrm{SB} 20$ are able to synthesize vitamin $\mathrm{B}_{3}$, in particular, its concentration is likely to increase, respectively, in $1.5(\mathrm{P}<0.05), 1.5(\mathrm{P}<0.05), 1.5$ $(\mathrm{P}<0.05)$ and $1.6(\mathrm{P}<0.001)$ times. Enterococci E. faecium $\mathrm{SB} 12$, E. durans $\mathrm{SB} 18$ and E. durans SB20 synthesize vitamin B5, the concentration of which increased, respectively, in $2.9(\mathrm{P}<0.05), 8.4(\mathrm{P}<0.05)$ and $9,5(\mathrm{P}<0.001)$ times compared to control.

3. When determining the macronutrients in the supernatant, where cultured strains of $E$. durans, SB6, E. faecium $\mathrm{SB} 12$, E. durans SB18 and E. durans SB20, found a probable increase in calcium levels, respectively, 1.8, 2.4, 1.6 and 1.4 times $(\mathrm{P}<0.05)$.

\section{References}

Asrar, F. M., \& O'Connor, D. L. (2005). Bacterially synthesized folate and supplemental folic acid are absorbed across the large intestine of piglets. $J$ Nutr Biochem, 16(10), 587-593. doi: 10.1016/j.jnutbio.2005.02.006.

Blencowe, H., Cousens, S., Modell, B., \& Lawn, J. (2010). Folic acid to reduce neonatal mortality from neural tube disorders. Int J Epidemiol, 39(1), 110-121. doi: 10.1093/ije/dyq028.
Didukh, N. A. (2008). Naukovi osnovy rozrobky tekhnolohii molochnykh produktiv funktsionalnoho pryznachennia: avtoref. dys.... na zdobuttia naukovoho stupenia d-ra tekhn. nauk: 05.18.16. Didukh Nataliia Andriivna, Odesa (in Ukrainian).

Gachak, Yu. R., Mikhailitskaya, O. R., Gutyj, B. V., Kuzio, L. R. \& Beliak, V. I. (2019). Dairy products of treatment and prophylactic action with the new cryopowder. Scientific Messenger of Lviv National University of Veterinary Medicine and Biotechnologies. Series: Food Technologies, 21(91), 110 117. doi: $10.32718 /$ nvlvet-f9119.

Gottshalk, G. (1982). Metabolizm bakterij. M.: Mir (in Russian).

Hachak, Yu., Gutyj, B., Nagovska, V., Slyvka, N., \& Ilnytska, A. (2018). Development of reciproces of dairy products of treatment and prophylaxic appointment with cryo powder. Scientific Messenger of Lviv National University of Veterinary Medicine and Biotechnologies, 20(85), 70-75. doi: $10.15421 /$ nvlvet 8513 .

Heyman, M., Terpend, K., \& Menard, S. (2005). Effects of specifi c lactic acid bacteria on the intestinal permeability to macromolecules and the infl ammatory condition. Acta Paediatr Suppl., 94(449), 34-36. doi: 10.1111/j.1651-2227.2005.tb02153.x.

Kapreliants, L. V., \& Iorhachova, K. H. (2003). Funktsionalni produkty. Odesa: Druk (in Ukrainian).

Korzun, V. V., Kozarin, I. P., \& Porac, A. M. (2007). Problema mikroelementiv u kharchuvanni naselennia Ukrainy ta shliakhy yii vyrishennia. Probl. kharchuvannia, 1, 5-11 (in Ukrainian).

Lahtin, V. M., Afanas'ev, S. S., \& Aleshkin, V. A. (2008). Strategicheskie aspekty konstruirovanija probiotikov budushhego. Vestnik Rossijskoj AMN, 2, 33-45 (in Russian).

Levitin, Ye. Ya., Vedernykova, I. O., Koval, A. O., \& Kryskiv, O. S. (2017). Bioaktyvnist neorhanichnykh spoluk: navch. posibn. dlia audyt. na samost. roboty studentiv. Kh.: NFaU (in Ukrainian).

Musiy, L., Tsisaryk, O., Slyvka, I., Mykhaylytska, O., \& Gutyj, B. (2017). Research into probiotic properties of cultured butter during storing. Eastern-European Journal of Enterprise Technologies, 3(11(87), 31-36. doi: 10.15587/1729-4061.2017.103539.

Omelchuk, S. T., Bilko, T. M., \& Akhtemiichuk, O. S. (2010). Rol alimentarnoho faktora v profilaktytsi imunosupresii. Materialy 6-yi Mizhnarodnoi naukovo-praktychnoi konferentsii "Rozvytok naukovykh doslidzhen 2010". Poltava: Interhrafika, 5, 76-79 (in Ukrainian).

Orlov, D. S. (1998). Mikrojelementy v pochvah i zhivyh organizmah. Sorosovskij obrazovatel'nyj zhurnal, 1, 61-68 (in Russian).

Richardson, D. P. (2002). Functional Food and Health Claims. The world of Functional ingredients, 9, 12-20.

Slyvka, I. M., Tsisaryk, O. Y., Dronyk, G. V., \& Musiy, L.Y. (2018). Strains of lactic acid bacteria isolated from traditional Carpathian cheese. Regul. Mech. Biosyst., 9(1), 62-68. doi: $10.15421 / 021808$.

Soccol, C. R., de Souza Vandenberghe, L. P. et al. (2010). The potential of probiotics: a review. Food Technol Biotechnol, 48(4), 413-434. URL: https://www.ftb.com.hr/archives/59volume-48-issue-no-4/119-the-potential-of-probiotics-areview.

Tarasenko, N. A., \& Filippova, E. V. (2014). Kratko o prebiotikah: istorija, klassifikacija, poluchenie, primenenie. Fundamental'nye issledovanija, 6(1), 33-35 (in Russian). 
Tkach, S. M., Puchkov, K. S., \& Sizenko, A. K. (2014). Kishechnaja mikrobiota $\mathrm{v}$ norme i pri patologii. Sovremennye podhody $\mathrm{k}$ diagnostike i korrekcii kishechnogo disbioza. K.: Tvisa LTD (in Russian).
Tsisaryk, O. Y., Slyvka, I. M., Musiy, L. Y., \& Kuschnir, I. I. (2018). Selection of lactic acid bacteria isolated from natural ecosystems for production of cultured butter for herodietic use. Scientific Messenger of Lviv National University of Veterinary Medicine and Biotechnologies, 20(85), 35-40. doi: $10.15421 /$ nvlvet8507. 